\title{
AKHLAK DAN ETIKA
}

\author{
Mohammad Faizin \\ Sekolah Tinggi Ilmu Syariah Darul Falah Bondowoso \\ Email : mohammadfaizindafa@gmail.com
}

\begin{abstract}
Abstrak
Sebagai suatu disiplin ilmu, akhlak dengan etika yang mengorientasikan kajiannya pada prilaku manusia dalam perspektif bagaimana seharusnya bukan apa adanya. Sehingga tidak sedikit dikalangan umat islam yang menterjemahkan akhlak dengan etika. Padahal antara keduanya berangkat dari suatu kajian yang berbeda serta dari suatu sumber yang berbeda pula. Akhlak dikembangkan dari sumber standar keislaman yaitu alqur'an dan sunnah. Sementara etika dikembangkan dari pemikiran otak manusia yaitu filsafat, sehingga yang satu sakral dan yang lainnya profan, yang satu dari langit dan yang lainnya dari bumi, yang satu kholiq, sedangkan yang lainnya dari makhluk. Pemikiran ini terasa tidak adil bila perilaku akhlak yang bersifat-bagaimana seharusnya itu didasarkan pada kejelekan, sehingga menjadi akhlakul qobiha atau al akhlakul madmumah. Apalagi kalau kemudian akhlak diyakini sebagai suatu ilmu keislaman, maka tentu sama sedang ilmu keislaman yang lain fikih, akidah, dan tasawwuf.
\end{abstract}

Kata Kunci : Akhlak, Etika

\section{Pendahuluan}

Akhlak yang merupakan karakter para rasul-rasul Allah, para nabiyullah serta para salafunassholeh menjadi panutan dan ikatan bagi generasi-generasi yang datang belakangan sekarang ini. Artinya apa yang dilakukan oleh generasi sekarang tak lain adalah hasil peniruan dari generasi sebelumnya sehingga terlihat baru, bila dicari akar permasalahannya akan bersambung dengan persoalan lama yang telah dihasilkan oleh masa lalu dan untuk selanjutnya terhubung dengan konsep dan ajaran agama yaitu alqur'an dan al-hadits. 
Suatu contoh tradisi ziarah kubur, tradisi berkunjung ke keluarga setelah berlebaran, tradisi baca al-qur'an dan lain sebagainya adalah mengakar pada konsep ajaran islam yang dibawa oleh para wali di negeri ini. Sementara tradisi judi dengan segala bentuknya, tradisi penanaman kepala kerbau bagi pembukaan industri baru, tradisi pembuatan cabul dalam upacara sakral dan lain sebagainya jelas tidak ada ketersambungan dengan konsep dan ajaran islam yaitu al-qur'an dan al-hadits.

Untuk kasus yang pertama, jelas sebagai perilaku yang bernilai akhlak karena disamping ketersambungannya dengan konsep dan ajaran islam juga sebagai warisan para salafunassholeh. Sedang untuk kasus yang kedua bukanlah prilaku yang bernilai akhlak tidak saja karena bersebrangan dengan konsep dan ajaran islam tetapi juga karena hal tersebut menjadi pekerjaan orang-orang yang ingkar dan selalu berbuat mafsadah dalam kehidupan ini ${ }^{1 .}$

Dari beberapa penjelasan diatas, nampak jelas adanya dua polarisasi sikap, prilaku dan karakter manusia, yaitu yang pertama sikap, prilaku dan akhlak yang bernilai (baik) dan yang kedua sikap, prilaku serta karakter di luar akhlak yang tidak bernilai (buruk), sehingga yang bernilai tidak akan pernah bertemu dengan apa yang tidak bernilai, seperti luar disatu sisi dan dalam pada sisi yang lain, dimana keduanya salalu terpisah dan tidak akan pernah menyatu. Logika ini akan memperjelas persoalan bahwa akhlak yang padanya melekat kebaikan tidak akan mungkin melekat (padanya) keburukan sama seperti tidak mungkinnya satu titik ditempati dua garis dalam waktu dan tempat yang bersamaan. $^{2}$

\section{Beberapa pendekatan}

Ada tiga pendekatan untuk mengembangkan beberapa pokok pikiran diatas yaitu, pendekatan etimologis, terminologis, dan epistimologis.

\section{Pendekatan etimologis}

Akhlak berasal dari bahasa arab yang menurut Jamil Saliba dalam Abuddin Nata adalah akhlako, yukhliqu, ikhlaqon, ikut wazan af'ala, yuf'ilu, if'alan yang berarti perangai, tabiat, watak dasar, kebiasaan, peradaban yang baik dan agama. ${ }^{3}$

Namun demikian Abuddin Nata mempertanyakan wazan tersebut sebagai asal dari kata akhlak, sebab bila hal tersebut benar berarti akhlak bukan akhlak, untuk itu menurutnya

\footnotetext{
${ }^{1}$ Hamzah Ya'qub, Etika Islam, Diponegoro Bandung, 1985

2 Ahmad Amin, Al-Akhlaq, Terjemahan Farid Makruf, Bulan Bintang, Jakarta.

${ }^{3}$ Abuddin Nata, Akhlak Tasawuf, PT. Raja Grapindo Persada, 1996
} 
akhlak adalah isim jamid atau ghairu mustaq yang memang demikian adanya. Sedang menurut Sidi Ghasalba, akhlak adalah jama' dari khuluq yang berarti perangai, tingkah laku, tabiat, bentuk kepribadian. ${ }^{4}$

Dari beberapa pendekatan ini dipahami bahwa apa yang kongkrit dari perbuatan manusia (kebiasaan, peradaban, tingkah laku) adalah cermin dari kondisi jiwanya (perangai, tabiat, watak dasar dan bentuk kepribadian). Dengan kata lain bahwa khulqun adalah bentuk luar dari kondisi dalam, khuluqun. Baik yang pertama, khulqun maupun yang kedua, khuluqun adalah akar dari kata akhlak.

Benarlah Sabda Nabi Muhammad SAW bahwa perbuatan kongkrit (a'mal) manusia menjadi sah bila keluar dari kondisi dalamnya (niat).

$$
\text { إنما الأعمال بالنيات }
$$

Dalam kerangka ini kondisi dalam seseorang (khuluq) sangat ditentukan oleh seberapa besar dan seberapa berpengaruh kometmen moralitas yang diserapnya, sehingga kualitas kongkrit perbuatan yang dimunculkan (khulqun) sebenarnya sama besar dan sejalan dengan komitmen moralitas yang mewarnai kondisi dalam diri seseorang itu. Hal ini memberikan pemahaman bahwa kondisi jiwa (khuluq) yang berupa komitmen moral (baik dan buruk) menjadi sentral bagi lahirnya kongkrit perbuatan seseorang dan warna dari perbuatan itu (khuluq) bisa baik dan bisa buruk.

Namun demikian dalam kerangka akhlak dalam hal tersebut bukanlah suatu pengakuan akan adanya akhlak yang buruk, tetapi hal itu tak lebih dari wujud suatu tantangan untuk dapatnya seseorang itu naik kesuatu tingkat keberuntungan yang dikehendaki Allah Swt. Allah berfirman :

$$
\text { قَدْ أَفْلَحَ مَنْ زَكَّهَا فَ وَقَدْ خَابَ مَنْ دَسَّهَا }
$$

Artinya:"Sungguh beruntunglah orang yang mensucikan jiwa itu, dan sungguh merugilah orang yang mengotorinya" (as-syam: 9-10).

Pengakuan adanya akhlak yang buruk hanya mengaburkan makna akhlak yang dikembangkan dari firman-firman Allah Swt. yang disebut al-qur'anul madzmum, mengapa harus ada akhlakul karimah.

2. Pendekatan terminologis

Banyak para ahli yang memberikan uraian tentang akhlak ini antara lain adalah:

a. Imam Al-Ghazali dalam kitab ihya' ulumuddin

\footnotetext{
${ }^{4}$ Sidi Gasalba, Azab Kebudayaan Islam, Bulan Bintang, 1978
} 
الخلق عبارة عن هيئة في النفس راسخة عنها تصد الانفعال بسهولة ويسر من غير حاجة الى فكرورؤية

"Akhlak adalah sifat yang tertanam dalam jiwa yang menimbulkan macam-macam perbuatan dengan gampang dan mudah, tanpa memerlukan pemikiran dan pertimbangan". 5

b. Abd. Hamid Yunus dalam Da'iratul Ma'arif

\section{"Akhlak adalah sifat-sifat manusia terdidik",}

Menurut Sidi Gazalba akhlak adalah sikap kepribadian yang melahirkan laku perbuatan manusia terhadap diri sendiri dan makhluk yang lain sesuai dengan suruhan dan larangan serta petunjuk al-qur'an dan al-hadits. ${ }^{7}$

Kajian terminologi akhlak diatas tidak satupun yang secara tegas mengindikasikan adanya akhlak yang buruk sungguhpun klasifikasi itu dapat saja dipahami dari terminologi Al-Ghazali yang menekankan bahwa prilaku kongkrit manusia itu berasal dari jiwa seseorang. Namun demikian secara naluri perbuatan buruk itu tidak dikehendaki oleh kata hatinya. Itu artinya bahwa perbuatan buruk adalah kegagalan manusia dalam mempertahankan kata hatinya yang tidak akan pernah berdusta menginformasikan nama yang baik untuk dikerjakan dan nama buruk untuk ditinggalkan.

Manusia yang mampu mengikuti kata hatinya oleh Allah dalam al-qur'an surat AliImron : disebut khairo ummah.

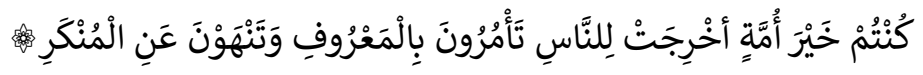

Artinya:"Kamu adalah umat yang terbaik yang dilahirkan untuk manusia, menyuruh kepada yang ma'ruf dan mencegah dari yang mungkar. (Ali-Imron : 110).

Manusia khairu ummah ini selalu menghias dirinya dengan akhlak para nabi, auliya' dan para salafunassholeh dimana al-qur'anul karim sebagai refrensinya.

Allah swt. Menjelaskan dalam al-qur'an surat As-Syuara':137.

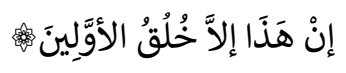

“(Agama kami) ini, tidak lain hanyalah kebiasaan orang dahulu”.

Perbuatan-perbuatan yang menyalahi perintah allah swt. (makruf) dan menerjang larangan al-qur'an disebut asariq (al-maidah: 38), munafiq (an-nisa': 45), musyrik (alan'am: 14), '’ash (an-nisa': 14), zanin (an-nur: 2) dan lain sebagainya. 
Bila demikian pengakuan adanya akhlak buruk hanya akan mengaburkan makna akhlak yang menjadi prilaku para nabi, rasul, auliya' dan para salafunassholeh sebagai manusia terdidik yang selalu berhias diri dengan al-qur'anul karim.

\section{Pendekatan epistimologis}

Secara epistimologis akhlak berbeda dengan disiplin ilmu lain yang bersifat deskriptif empiris dimana segala kajian diambil dari hasil analisis terhadap fenomena objek seperti apa adanya, sementara akhlak bersifat formal normatif yang meletakkan hasil kajian untuk bagaimana seharusnya seperti yang telah ditunjuk oleh suruhan serta larangan Allah dan rasulnya serta seperti yang telah diletakkan dasar-dasarnya oleh para auliya', anbiya', dan para salafunassholeh.

Akhlak sama dengan etika dalam hal meletakkan hasil kajian yang bersifat bagaimana seharusnya, namun pada etika apa yang bersifat formal normatif, diangkat dari sifat sementara akhlak dari al-qur'an dan al-hadits. Etika merupakan hasil perenungan dan pemikiran otak manusia sedang akhlak dari Allah dan rasulnya. ${ }^{8}$

Disamping itu akhlak dikembangkan dari sabda nabi Muhammad Saw. dalam kapasitas beliau sebagai nabi dan rasul allah swt:

"Aku diutus untuk menyempurnakan akhlak".

Demikian juga etika dibatasi oleh ruang dan waktu sedang akhlak bersifat universal.

Cukuplah (kata mereka) bahwa etika itu meneliti tentang kebaikan saja, seperti yang dikatakan Prof. Ir. Poedjawijata sebagai berikut:

"Sudah cukuplah jika dikatakan bahwa etika hendak mencari ukuran baik, yang tidak sesuai dengan ukuran baik adalah buruk atau jahat. Tugas etika menurutnya adalah untuk mengetahui bagaimana orang seharusnya berbuat". 9

Demikian juga dalam bahasa sehari-hari dikenal adanya bentuk kata positif sebagai lawan dari bentuk negatif, moral lawan amoral atau dekadensi moral, sehingga dalam diskursus ini tidak dikenal adanya bentuk, moral jelek, etika jelek, dan lain sebagainya. Sejalan dengan Prof. Ir. Poedjawijata, Dr. Musa Subaiti mengatakan bahwa akhlak adalah perbuatan yang lahir dari kemauan dan pemikiran serta mempunyai tujuan yang jelas. Tujuan tersebut secara subtansial harus baik dan indah. Menurutnya adanya konsep negatif dalam akhlak, adalah justru terjadi kemunduran umat islam dimana kekuasaan beralih dari bangsa arab ke bangsa turki dan tartar, lalu akhlakpun menjadi jauh dari kehidupan masyarakat. ${ }^{10}$ Bila demikian pengakuan akan adanya akhlak yang 
buruk hanya akan mengaburkan makna akhlak itu sendiri dan hanya akan kemunduran islam.

\section{Penutup}

Sikap manusia dalam kehidupan sehari-hari tidak lepas akhlak dan etika yang diperankannya. Baik buruknya manusia terlihat seberapa bagus akhlak dan etikanya dengan orang lain. Manusia akan tampak baik, apabila memerankan diri dengan akhlak dan etika yang baik. Sebagian dari akhlak yang baik (mahmudah) adalah tersenyum saat bertemu dengan orang, tutur kata yang sopan, lemah lembut. Jika orang yang berperangai seperti itu memang benar adanya tanpa adanya tendensi apapun, maka defenisi akhlak sebenarnya menjadi absah. Akan tetapi bila akhlak hanyalah dijadikan perisai diri untuk kepentingan tertentu, maka yang demikian tidak termasuk pengertian akhlak yang sesungguhnya dalam perpsektif etimologis. Pembagian akhlak kepada mahmudah dan madzmumah adalah wilayah kajian terminologis. Secara epistimologis akhlak tidak dapat dipertentankan antara yang baik dan yang buruk. Baik dan buruknya akhlak dalam teori ilmu pengetahuan bisa bersifat normatif. Artinya orang akan dilihat orang lain berakhlak dan beretika apabila ia mematuhi norma-norma dan aturan yang telah disepakati bersama. Misalnya, anggota pengedar narkoba bila taat pada aturannya ketua pengedar, maka ketua pengedar akan melihat sebagai anggotanya sebagai orang yang baik. Dengan demikian perlu ditekankan bahwa ada perbedaan bahwa akhlak bersumber dari standar aturan normatif ketuhanan yaitu berdasarkan al-quran dan hadits. Sedangkan etika merupakan hasil dari pemikiran manusia. 


\section{Daftar Pustaka}

Alquran dan terjemahnya. Depag.RI 1993

Ya'qub, Hamzah, Etika Islam, Diponegoro Bandung, 1985

Amin, Ahmad, Al-Akhlaq, Terjemahan Farid Makruf, Bulan Bintang, Jakarta.1997

Nata, Abuddin, Akhlak Tasawuf, PT. Raja Grapindo Persada, 1996

Gazalba, Sidi, Azab Kebudayaan Islam, Bulan Bintang, 1978 